\title{
Factors associated with adherence to antiretroviral therapy in HIV/AIDS patients: a cross-sectional study in Southern Brazil
}

C.A.T. Pinheiro ${ }^{1}$

J.C. de-Carvalho-Leite²,

M.L. Drachler 3,4

and V.L. Silveira ${ }^{1}$

\begin{abstract}
${ }^{1}$ Serviço de Assistência Especializada em HIV/AIDS, Faculdade de Medicina, Universidade Federal de Pelotas, Pelotas, RS, Brasil

${ }^{2}$ Faculdade de Psicologia, Universidade de Caxias do Sul, Caxias do Sul, RS, Brasil

${ }^{3}$ Faculdade de Medicina, Universidade de Caxias do Sul, Caxias do Sul, RS, Brasil

${ }^{4}$ Ciências da Saúde, U niversidade Vale do Rio dos Sinos, São Leopoldo, RS, Brasil
\end{abstract}

\section{Correspondence}

C.A.T. Pinheiro

SAE, Faculdade de Medicina Universidade Federal de Pelotas

Parque D. Antônio Zattera, 379/201

96015-180 Pelotas, RS

Brasil

Fax: + 55-53-221-3553

E-mail: cezarart@zaz.com.br

.....................

This research is part of a Master's thesis in Health and Behavior presented by C.A.T. Pinheiro at the Universidade Católica de Pelotas, Pelotas RS, Brazil.

Received April 18, 2002 Accepted August 13, 2002

\section{Abstract}

A cross-sectional study was conducted on HIV-infected adults being treated with antiretroviral drugs at a reference service in Southern Brazil. Participants answered a sociodemographic questionnaire and were tested by scales assessing sociocognitive variables. Adherence to treatment was assessed by a self-report inventory developed for the study. Clinical information was obtained from the patients' records. Significance tests were conducted using univariate logistic regressions followed by multivariate logistic regression analysis. A total of 195 patients participated in the study and $56.9 \%$ of them reported $\geq 95 \%$ adherence on the previous two days. In univariate analysis, the odds of adherence increased with self-efficacy (a person's conviction that he/she can successfully execute the behavior required to produce a certain desired outcome) in taking medications as prescribed $(\mathrm{OR}=$ $3.50,95 \%$ CI 1.90-6.55), and decreased with perception of negative affect and physical concerns $(\mathrm{OR}=0.71,95 \% \mathrm{CI} 0.53-0.95)$. The odds were lower for taking antiretroviral medications $>4$ times a day $(\mathrm{OR}=$ $0.44,95 \%$ CI $0.20-0.94)$ and higher for patients with 8 years of schooling $(\mathrm{OR}=2.28,95 \% \mathrm{CI} 1.12-4.66)$. In the multivariate analysis, self-efficacy $(\mathrm{OR}=3.33,95 \% \mathrm{CI} 1.69-6.56)$ and taking medication $>4$ times a day $(\mathrm{OR}=0.34,95 \%$ CI $0.14-0.80)$ were independently associated with adherence. Self-efficacy was the most important predictor of adherence, followed by number of times antiretroviral medication was taken per day. Among sociodemographic and clinical variables, only the number of years of schooling was associated with adherence. Motivational interventions based on self-efficacy may be useful for increasing treatment adherence.

\section{Introduction}

The advent of highly active antiretroviral treatment has dramatically improved the prognosis for HIV-positive patients, substantially reducing the rate of disease progression and

\section{Key words}

- Adherence

- Antiretroviral therapy

- Self-efficacy

- HIV

- AIDS death (1-4). Adherence to antiretroviral therapy, however, is critically important for the success of the therapy. The study by Paterson et al. (5) suggests that near-perfect adherence, i.e., higher than $95 \%$, is necessary to achieve suppression of HIV replication 
(HIV-RNA $<400$ copies/ml). Inadequate viral suppression resulting from failure to adhere closely to treatment (5-10) causes a worsening of immunological and clinical states and leads to emergence of drug-resistant HIV strains $(11,12)$.

Many factors have been studied for their association with the behavior of taking antiretroviral medication correctly. Sociodemographic characteristics were not associated with adherence in some studies (13-17). The following factors have been associated with nonadherence in a number of studies: sociodemographic characteristics such as younger age $(5,18,19)$, African ascendance $(20,21)$, low income $(21,22)$, low levels of schooling $(22,23)$ and psychological factors such as depression $(19,20,24)$, high levels of stress $(17,20)$, psychiatric conditions $(5,20)$, excessive drinking $(16,17,25)$, and drug use $(16,17,19)$. Some studies also suggest that nonadherence tends to increase with the number of times medications must be taken per day $(14,26)$ and the number of different medications (21). Patients who are experiencing adverse effects are less likely to adhere than patients who are tolerating the medication $(27,28)$.

Some studies have investigated patient attitudes towards antiretroviral treatment. The perceived convenience of the antiretroviral regimen, or "fit" with routine and daily activities was associated with better adherence (10). Patients who were less sure of the link between nonadherence and the development of drug resistance were less adherent (17). Selfefficacy expectations (29) of antiretroviral therapy may be a promising aspect of patient attitude towards treatment. Cross-sectional studies $(10,14,17,24)$ have suggested that low levels of self-efficacy expectation to take medication as prescribed were associated with nonadherence to antiretroviral therapy. A prospective randomized two-arm controlled study (25) showed that a specific educative intervention increased maintenance of high levels of adherence during one-year follow-up. In this prospective study, perceived self-efficacy and effort to take medication were associated with a high-level adherence one year after beginning therapy.

The present study investigated factors which may be associated with adherence among HIV-infected patients in Southern Brazil. The identification of factors associated with adherence may provide the basis for future interventions to increase the effectiveness of this type of therapy.

\section{Material and Methods}

A cross-sectional study was conducted at a publicly funded specialist clinic in the city of Pelotas (Southern Brazil) where medical care is delivered free of charge. Patients aged 13 or above who had initiated antiretroviral therapy between January 1998 and September 2000 were selected for the study. Patients were approached by trained interviewers in the clinic. Those not attending the service regularly were reached through home visits and interviewed. The research plan was approved by the University Ethics Committee and all patients signed an informed consent document before participating in the study. The interviewers were not aware of the antiretroviral medication prescribed to the patients.

Patients answered a questionnaire investigating sociodemographic characteristics such as age, gender, education and family income, and other structured questionnaires assessing the following attitudes towards treatment: adherence to antiretroviral therapy, self-efficacy expectations for adherence to antiretroviral therapy, outcome expectations of antiretroviral therapy, and perceptions of negative affects and physical concerns. The self-efficacy and the outcome expectation questionnaires were created by de-Carvalho-Leite et al. (30), and the questionnaires on adherence and perceptions of negative affects and physical concerns were developed for this study. 
Adherence to antiretroviral therapy in the previous $48 \mathrm{~h}$ of the interview was measured by self-report. Initially, the percent of adherence was calculated for each drug by dividing the number of pills taken by the number of pills prescribed. Then, the percent of adherence to the antiretroviral regimen was estimated by the average of adherence to the drugs. Patients who reported an intake of $95 \%$ or more of the prescribed medication were considered to be adherent.

Self-efficacy expectations for adherence to antiretroviral therapy (personal confidence in the ability to adhere to antiretroviral medication) were measured using a 21 -item questionnaire: "When I feel very healthy", "When my viral load is very low (undetectable)", "When I am feeling depressed or disliked", "When I am feeling discriminated or rejected", "When I am busy or having a good time", "While traveling", "When I am away from home", "When I feel very ill", "When somebody is with me and I don't want my HIV status disclosed", "When I have too many pills to take", "When I am feeling angry inside or nervous", "When I have to take pills many times a day", "While strangers are watching me", "When the pills are difficult to swallow", "During the weekend or holidays", "When my meals or sleep times are changed because of the treatment schedules", "When the pills taste or smell bad", "When my daily routine is changed because I am doing other things", "When somebody tells me that to take these pills is foolish", "When I feel that the drug is toxic/harmful (the drug has adverse effects)", "When my attending physician is changed frequently". For each item the patient indicated on a Likert scale (coded from 0 to 4 ), how confident they were that they would take the medication as prescribed, during the next month. The internal consistency (Cronbach's $\alpha$ ) of the HIV-medication selfefficacy scale was 0.93 , suggesting very high reliability.

Outcome expectations of antiretroviral therapy were measured using a 11-item questionnaire assessing positive outcome expectations (5 items on positive affects on health) and negative outcome expectations (6 items on side effects, interference with daily routines and having one's HIV status disclosed). The items assessing positive outcome expectations are: "I will be taking the best pills for my disease", "My laboratory exams will be good", "My health will be protected", "My appearance will be good and healthy", "My life will be prolonged". The items assessing the negative outcome expectations are: "I will have some adverse drug effects", "Some people will discover my HIV status", "I will have to put up with somebody asking me why I am taking pills", "The treatment will change my daily routine especially when the time of taking pills coincides with my meals or bedtime", "Before leaving home I will spend time organizing myself to take the pills according to schedule", "I will have difficulty in swallowing pills". Patients indicated on a Likert scale (coded from 0 to 4 ) how much they agree that the situation described in the item will occur if the medication is taken according to prescription. The internal consistency (Cronbach's $\alpha$ ) of these subscales was 0.79 and 0.62 , respectively, suggesting acceptable reliability.

Perceptions of negative affects and physical concerns were measured using a scale developed in the same study that generated the previous scales and that includes five items: "I have been feeling sad and down", "I have been nervous and irritable", "I have been feeling unwell", "I have had trouble getting things done", and "I feel weak and sick". A Likert scale was added to each of these items using the same coding and alternatives as the treatment outcome expectation scale. The Cronbach $\alpha$ index for this scale was 0.75 , indicating acceptable reliability.

The scores of the scales for self-efficacy expectation and perception of negative affects and physical concerns were obtained 
using the first principal component of an exploratory factor analysis by the regression method. For the outcome expectation scales, the principal component analysis with oblique rotation showed that the negative items loaded highly $(>0.45)$ on the first factor, and the positive items loaded highly on the second one. Scores for the positive and negative outcome expectations were obtained by the extraction of these factors using the same regression method.

Information about current antiretroviral regimen, clinical condition, and prophylaxis and/or treatment of opportunistic infections and the lowest level of CD4 was obtained from medical records.

After the interviews, the subjects provided blood samples for plasma HIV RNA determination and CD4 lymphocyte counts. Quantitative plasma HIV RNA levels were determined using nucleic acid sequence-

Table 1. Characteristics of the patients $(\mathrm{N}=195)$.

\begin{tabular}{|c|c|}
\hline \multicolumn{2}{|l|}{ Characteristics } \\
\hline Male, N (\%) & $119(61)$ \\
\hline Age (years), mean (range) & $35(17-67)$ \\
\hline Years of schooling, median (range) & $5(0-15)$ \\
\hline Monthly family income (minimum wage), median (range) & $1.65(0-46.3)$ \\
\hline \multicolumn{2}{|l|}{ Household status, N (\%) } \\
\hline Living alone & $28(14.4)$ \\
\hline Living with someone & 167 (85.6) \\
\hline Work for pay outside the home, $\mathrm{N}(\%)$ & $77(39.5)$ \\
\hline \multicolumn{2}{|l|}{ CDC group, $\mathrm{N}(\%)$} \\
\hline A & $55(28.2)$ \\
\hline $\mathrm{B}$ & $22(11.3)$ \\
\hline $\mathrm{C}$ & $118(60.5)$ \\
\hline \multicolumn{2}{|l|}{ Viral load (copies/ml) } \\
\hline$<80$ & $91(46.7)$ \\
\hline $80-10,000$ & $37(22.7)$ \\
\hline$>10,000$ to $\leq 100,000$ & $29(14.9)$ \\
\hline$>100,000$ & $23(11.8)$ \\
\hline \multicolumn{2}{|l|}{ CD4 cell count (cells/mm³) } \\
\hline$\leq 200$ & $44(22.6)$ \\
\hline$>200$ & $151(77.4)$ \\
\hline \multicolumn{2}{|l|}{ Number of antiretroviral medication, $\mathrm{N}(\%)$} \\
\hline 2 & $26(13.3)$ \\
\hline 3 & $152(77.9)$ \\
\hline 4 & $17(8.7)$ \\
\hline
\end{tabular}

based amplification (31) with a lower limit of 80 copies/ml CD4 lymphocytes were counted by flow cytometry. All information was entered into the database twice, by different persons, using the Epi Info 6.0 software.

\section{Statistical analysis}

Adherence and nonadherence rates were estimated for each category of the independent variables, sociodemographic and clinical. The means and standard deviations of continuous independent variables, sociocognitive variables and perception of negative affects and physical concerns, were calculated for adherent and nonadherent patients. Comparisons of all variables and of adherence were made using odds ratios (OR) with $95 \%$ confidence intervals. The dependent variable was $\geq 95 \%$ adherence versus $<95 \%$ adherence. HIV RNA measurements were compared with the self-reported adherence as a means of supporting the validity of the self-reports.

The independent predictors of adherence were assessed using a sequence of two multivariate logistic regression models employing the SPSS 8.0 software: initially, a model was set up with adjustments for sociodemographic, clinical and antiretroviral regimen variables; next, a second model was constructed by taking sociodemographic, clinical, antiretroviral regimen and four cognitive variables into account. Variables selected for inclusion in subsequent models were based on their significance (e.g., $\mathrm{P}<0.2$ ) in bivariate analyses or in a prior model.

\section{Results}

Of the 232 patients selected, 195 were included in the study, 10 had died and 27 were not located. The characteristics of the patients studied are summarized in Table 1. Of the 195 patients in the study, 119 were men, ranging in age from 17 to 67 years 
(mean: 35 years). The majority $(69.2 \%)$ had seven years of schooling or less. The family income was less than US\$225.00/month for $73.8 \%$ of the sample. Of these patients, $14.4 \%$ were living alone and only $39.5 \%$ worked for pay outside the home. A total of 118 patients $(60.5 \%)$ were classified in stage $\mathrm{C}$ (Centers for Disease Control and Prevention, CDC), 151 (77.4\%) had a CD4 count below 200 cells $/ \mathrm{ml}$, and $91(46.7 \%)$ had an undetectable viral load $(<80$ copies $/ \mathrm{ml})$. Antiretroviral regimens consisted of two different drugs for $13.3 \%$ of patients, of three in $77.9 \%$, and four in $8.7 \%$. The time on this treatment was less than 18 months for $62.7 \%$ of the sample. Adherent patients, with $\geq 95 \%$ of the antiretroviral medication taken on the last two days, corresponded to $56.9 \%$ of the subjects. These patients had a greater prevalence of viral load of less than 500 copies/ $\mathrm{ml}$, i.e., $67.5 \%$ as opposed to $31.5 \%$ among nonadherent patients $\left(\chi^{2}=16.57, \mathrm{P}<0.001\right)$.

Among the sociodemographic variables (Table 2), schooling was associated with better adherence, with an increase in rates of adherence with increasing schooling levels (test for trend, $P=0.02$ ). Age, gender or family income was not associated with reported $\geq 95 \%$ adherence. Among clinical and regimen characteristic variables (Table 3 ), frequency of medication ingestion was associated with adherence to antiretroviral therapy; patients taking antiretroviral medications $>4$ times/day reported lower adherence than patients with antiretroviral medications taken twice a day $(\mathrm{OR}=0.44,95 \%$ CI $0.20-0.94)$. The rate of adherence to antiretroviral treatment decreased with increasing numbers of time per day when antiretroviral medication had to be taken (test for trend, $\mathrm{P}=0.03$ ). Stage of disease (CDC), time when antiretroviral therapy was started or perceived adverse drug effects was not associated with adherence.

Table 4 presents sociocognitive variables (means $\pm \mathrm{SD}$ ) for adherent and nonadherent patients and odds ratios, both crude and adjusted for sociodemographic, clinical, and sociocognitive variables. Self-efficacy expectation, the perception of negative affects and physical concerns were associated with adherence. The self-efficacy scores were higher among the patients who were adherent to antiretroviral treatment ( $t$-test, $\mathrm{P}<0.001$ ), while the average scores of perception of negative affects and physical concerns were higher among the nonadherent patients ( $t$-test, $\mathrm{P}=0.02)$.

Two multiple logistic regression models were used to assess the independent predictors of adherence. Initially, analysis was carried out adjusted for sociodemographic (age, gender, years of schooling, family income), clinical (CDC group), and regimen characteristic variables. At this level, years of schooling (Table 2, adjusted a) and number of times per day when antiretroviral medication had to be taken (Table 3, adjusted b)

Table 2. Total number of patients in each group and percentages of adherent patients/ group ( $\geq 95 \%$ adherence).

\begin{tabular}{|c|c|c|c|c|c|}
\hline & \multirow{2}{*}{$\begin{array}{c}\text { Total } \\
\mathrm{N}\end{array}$} & \multirow{2}{*}{$\begin{array}{c}\geq 95 \% \\
\text { Adherence } \\
(\%)\end{array}$} & \multicolumn{3}{|c|}{ Odds ratio $(95 \% \mathrm{Cl})$} \\
\hline & & & Unadjusted & Adjusteda & Adjusted ${ }^{b}$ \\
\hline \multicolumn{6}{|l|}{ Gender } \\
\hline Male & 119 & 52.1 & 1 & 1 & 1 \\
\hline Female & 76 & 64.5 & $1.66(0.92-3.01)$ & $1.83(0.94-3.54)$ & $1.61(0.80-3.22)$ \\
\hline \multicolumn{6}{|l|}{ Age (years) } \\
\hline $15-24$ & 31 & 61.3 & $0.31(0.12-0.78)$ & $0.47(0.18-1.25)$ & $0.46(0.16-1.28)$ \\
\hline $25-34$ & 70 & 50.0 & $0.46(0.22-0.99)$ & $1.01(0.38-2.66)$ & $0.70(0.25-1.99)$ \\
\hline $35-44$ & 63 & 65.1 & 1 & 1 & 1 \\
\hline$\geq 45$ & 31 & 51.6 & $0.50(0.19-1.30)$ & $0.59(0.20-1.78)$ & $0.51(0.16-1.63)$ \\
\hline \multicolumn{6}{|c|}{ Years of schooling } \\
\hline $0-4$ & 73 & 47.9 & 1 & 1 & 1 \\
\hline $5-7$ & 62 & 57.1 & $1.44(0.82-3.33)$ & $1.56(0.73-3.34)$ & $1.70(0.75-3.88)$ \\
\hline$\geq 8$ & 60 & 67.8 & $2.28(1.12-4.66)$ & $2.26(1.02-5.02)$ & $1.73(0.75-3.98)$ \\
\hline \multicolumn{6}{|c|}{ Family income (minimum wage/month`) } \\
\hline$<1$ & 39 & 51.3 & 1 & 1 & - \\
\hline $1-1.9$ & 74 & 54.1 & $1.12(0.51-2.43)$ & $1.52(0.65-3.57)$ & - \\
\hline$\geq 2$ & 82 & 62.2 & $1.56(0.72-3.37)$ & $1.55(0.57-4.23)$ & - \\
\hline
\end{tabular}

aAdjusted for gender, age, formal education, number of times per day antiretroviral medication must be taken, and self-report of adverse effects.

bAdjusted for gender, age, formal education, number of times per day antiretroviral medication must be taken, self-report of adverse effects, and sociocognitive variables. cMinimum wage, US\$ 75.00. 95\% Cl, 95\% confidence interval. 
Table 3. Total number of patients in each group and percentages of adherent patients/ group ( $\geq 95 \%$ adherence).

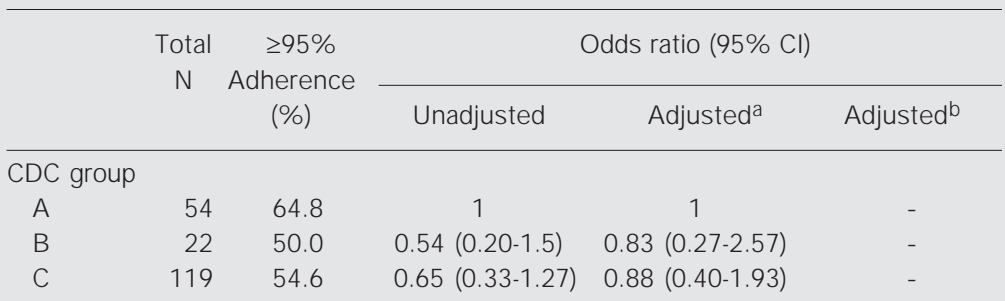

Number of times per day medication must be taken in the antiretroviral regimen

$\begin{array}{lllccc}2 & 70 & 65.7 & 1 & 1 & 1 \\ 3-4 & 79 & 55.7 & 0.66(0.34-1.27) & 0.67(0.33-1.38) & 0.71(0.34-1.53) \\ 5-6 & 46 & 45.7 & 0.44(0.20-0.94) & 0.39(0.16-0.92) & 0.34(0.14-0.80)\end{array}$

Time since starting antiretroviral therapy (months)

\begin{tabular}{lccccc}
$<6$ & 67 & 62.7 & 1 & 1 & - \\
$6-18$ & 65 & 50.8 & $0.61(0.31-1.23)$ & $0.56(0.26-1.19)$ & - \\
$\geq 18$ & 63 & 57.1 & $0.79(0.39-1.60)$ & $0.71(0.33-1.54)$ & - \\
\multicolumn{7}{c}{ elf-report of adverse effects } & of therapy \\
No & 119 & 62.2 & 1 & 1 & 1 \\
Yes & 76 & 48.7 & $0.57(0.31-1.03)$ & $0.58(0.31-1.10)$ & $0.59(0.30-1.16)$
\end{tabular}

aAdjusted for gender, age, formal education, number of times per day antiretroviral medication must be taken, and self-report of adverse effects.

bAdjusted for gender, age, formal education, number of times per day antiretroviral medication must be taken, self-report of adverse effects, and sociocognitive variables. $95 \% \mathrm{Cl}, 95 \%$ confidence interval.

Table 4. Sociocognitive variables for antiretroviral therapy - nonadherent vs adherent patients.

\begin{tabular}{|c|c|c|c|c|}
\hline \multirow[t]{2}{*}{ Variable } & \multicolumn{2}{|c|}{ Mean (SD) score } & \multirow[t]{2}{*}{ OR $(95 \% \mathrm{Cl})^{\mathrm{a}}$} & \multirow[t]{2}{*}{ OR $(95 \% \mathrm{Cl})^{b}$} \\
\hline & Adherent & Nonadherent & & \\
\hline $\begin{array}{l}\text { Self-efficacy } \\
\text { expectation }\end{array}$ & $0.28(0.40)$ & $-0.37(1.37)$ & $\begin{array}{c}3.5(1.90-6.55) \\
\quad P<0.001\end{array}$ & $\begin{array}{c}3.33(1.69-6.56) \\
P<0.001\end{array}$ \\
\hline $\begin{array}{l}\text { Perception of } \\
\text { negative affects and } \\
\text { physical concems }\end{array}$ & $-0.14(0.99)$ & $0.19(0.99)$ & $\begin{array}{c}0.71(0.53-0.95) \\
P=0.02\end{array}$ & $\begin{array}{c}0.67(0.60-1.25) \\
P=0.44\end{array}$ \\
\hline $\begin{array}{l}\text { Positive outcome } \\
\text { expectations }\end{array}$ & $0.11(1.00)$ & $-0.14(0.98)$ & $\begin{array}{c}1.29(0.97-1.72) \\
P=0.08\end{array}$ & $\begin{array}{c}1.12(0.80-1.57) \\
P=0.50\end{array}$ \\
\hline $\begin{array}{l}\text { Negative outcome } \\
\text { expectations }\end{array}$ & $-0.06(0.10)$ & $0.08(1.00)$ & $\begin{array}{c}0.87(0.65-1.16) \\
P=0.34\end{array}$ & $\begin{array}{c}1.23(0.87-6.56) \\
P=0.24\end{array}$ \\
\hline
\end{tabular}

Crude odds ratios and adherence odds ratios adjusted for sociocognitive variables. aUnadjusted.

bAdjusted for gender, age, formal education, number of times per day antiretroviral medication must be taken, self-report of adverse effects and sociocognitive variables. OR, odds ratio; $95 \% \mathrm{Cl}, 95 \%$ confidence interval. were associated with adherence to antiretroviral therapy.

The sociocognitive variables were then added to the model adjusted by years of schooling and number of times per day when antiretroviral medication had to be taken (Table 4). In this final adjusted model, the odds of adherence were 3.33 times greater when self-efficacy scores increased by one unit. Perceptions of negative affects and physical concerns were not statistically significant, demonstrating a lack of evidence for their effect on adherence to antiretroviral therapy.

\section{Discussion}

The objective of this study was to investigate associations between the adherence to antiretroviral therapy and sociodemographic, clinical, and sociocognitive variables. It was limitated by its cross-sectional design, i.e., the associations could not be interpreted as causal; also, there is no knowledge about the temporal relationships between independent variables and outcome, concerning sociocognitive variables. Although comparable with other studies $(16,19)$, the prevalence of adherence to treatment in the present study was low $(56.9 \%)$. There was a significant association between adherence and viral load below 500 copies $/ \mathrm{ml}$, thus further validating the adherence self-report measure. This method has frequently been employed in antiretroviral research $(10,14,16,17,19$, $22,26)$ due to its practicality, low cost, and to the fact that the adherence detected by it has proved to be related to viremia below detection limits $(9,10,16,17)$ and to serum levels of protease inhibitors (32).

Similar to the results of other studies (1317), there was no evidence for the association between sociodemographic characteristics gender, age, and income and adherence to antiretroviral medication. In our study, the prevalence of adherence increased with the number of years of schooling. More than 
eight years of schooling and adherence were associated even after adjustment for other sociodemographic and clinical variables. After adding self-efficacy expectations to the model, schooling of more than eight years was no longer statistically significant, probably because education is a determinant of self-efficacy. In the present study, patients with more years of schooling had higher self-efficacy scores than those with fewer years of schooling. Indeed, a fundamental goal of education is to equip the individual with the ability to plan, to organize instructive activities, and to integrate new information to previous knowledge (33). Similar to the results of other studies $(10,19,22,23)$, patients with more years of schooling showed a greater prevalence of adherence to treatment.

Among the clinical and regimen characteristic variables, only the number of times per day antiretroviral medication had to be taken was associated with adherence, in agreement with other studies and reviews $(22,26,27)$. The greater the number of doses to be taken per day, the more difficult is treatment adaptation. This has been reported by patients as a reason for missing doses $(17,21,34)$.

There was no evidence of association between adherence and the expectations of positive or negative outcomes of treatment, while self-efficacy expectations had strong and positive effects. These results support Bandura's (33) social-learning theory hypothesis that self-efficacy expectation is a more central determinant of adherence to health behaviors than outcome expectation. People act on their beliefs about what they can do as well as their beliefs about the likely effects of various actions. The potential motivating effects of the outcome expectations of a particular health behavior (i.e., adherence to antiretroviral treatment) is partly governed by beliefs in personal capabilities. There are many activities that, if done well, guarantee valued outcomes, but they are not likely to be pursued by people who doubt they can do what it takes to succeed. Conversely, firm belief in one's efficacy can sustain efforts over prolonged periods of time even in view of an uncertain or repeated negative outcome (33).

The perception of negative affects and physical concerns was inversely associated with nonadherence in the unadjusted model, in agreement with other studies showing that depression, stress and psychiatric conditions are risk factors for non-adherence $(5,17,19$, 20,24). Furthermore, the evidence for association between negative affects and physical concerns and self-efficacy expectation supports the view that physical and emotional conditions at the time of performing a behavior are one of the sources of self-efficacy expectation (33).

In the multivariate analysis, self-efficacy expectation was the variable most strongly associated with adherence. This association was also reported in other studies $(10,14,17$, $24,25)$. In agreement with Bandura's sociocognitive theory (33), individuals who do not believe in their ability to adhere to treatment would tend to make less effort towards adopting measures to facilitate adherence or to modify behaviors which increase the risk of nonadherence. Self-efficacy expectation may influence adherence by acting on motivational, cognitive, and emotional processes, thus changing the meaning and value of external influences, the evaluation of the consequences of following treatment, and treatment-related choices.

Self-efficacy expectation has been widely used to understand and intervene in compliance with health-protecting behaviors related to AIDS prevention $(35,36)$, management of chronic diseases (37), and positivehealth behaviors $(38,39)$. An intervention study was carried out based on Bandura's social-learning theory regarding treatment of HIV-infected patients (25). The study showed an increase in the adherence to antiretroviral treatment as patient self-efficacy 
expectation increased. Interventions like this act on self-efficacy by identifying high-risk situations for nonadherence and providing psychological and instrumental support for the patients.

The sociocognitive questionnaires (30) used in the present study may be useful for the clinical assessment of HIV patients. Pa- tient resources to cope successfully with high-risk situations for nonadherence to treatment can be identified, and those with low levels of self-efficacy in taking the antiretroviral medication may be supported by interventions in situations in which their ability to adhere is weak.

\section{References}

1. Hogg RS, Heath KV, Yip B, Craib KJ, O'Shaughnessy MV, Schechter MT \& Montaner JS (1998). Improved survival among HIV-infected individuals following initiation of antiretroviral therapy. J ournal of the American Medical Association, 279: 450-454.

2. Palella FJ, Delaney KM, Moorman AC, Loveless MO, Fuhrer J, Satten GA, Aschman DJ \& Holmberg SD (1998). Declining morbidity and mortality among patients with advanced human immunodeficiency virus infection. HIV Outpatient Study Investigators. New England J oumal of Medicine, 338: 853-860.

3. Mocroft A, Vella S, Benfield TL, Chiesi A, Miller $V$, Gargalianos P, d'ArminioMonforte A, Yust I, Brun J N, Phillips AN \& Lundgren J D (1998). Changing patterns of mortality across Europe in patients infected with HIV. Lancet, 3521: 17251730.

4. Coordenação Nacional de DST/AIDS do Brasil (2002). A experiência do programa brasileiro de AIDS. Available at http:// www.aids.gov.br/final/biblioteca/ resposta/resp espanhol.pdf. Accessed September 6, 2002.

5. Paterson DL, Swindells S, Mohr J, Brester $M$, Vergis EN, Squier $C$, Wagener MM \& Singh N (2000). Adherence to protease inhibitor therapy and outcomes in patients with HIV infection. Annals of Internal Medicine, 133: 21-30.

6. Monforte A, Testa L, Adomi F, Chiesa E, Bini T, Moscatelli C, Abeli C, Rusconi S, Sollima S, Balotta C, Musicco M, Galli M $\&$ Moroni M (1998). Clinical outcome and predictive factors of failure of highly active antiretroviral therapy in antiretroviralexperienced patients in advanced stages of HIV-1 infection. AIDS, 12: 1631-1637.

7. Lucas GM, Chaisson RE \& Moore RD (1999). Highly active antiretroviral therapy in a large urban clinic: Risk factors for virologic failure and adverse drug reac- tions. Annals of Internal Medicine, 131: 81-87.

8. Descamps D, Flandre $P$, Calvez $V$, Peytavin G, Meiffredy V, Collin G, Delaugerre C, Robert-Delmas S, Bazin B, Aboulker J P, Pialoux G, Raffi F \& BrunVezinet $F$ (2000). Mechanisms of virologic failure in previously untreated HIV-infected patients from a trial of inductionmaintenance therapy. Trilège (Agence Nationale de Recherches sur le SIDA 072 Study Team). J ournal of the American Medical Association, 283: 205-211.

9. Bangsberg DR, Hecht FM, Charlebois ED, Zolopa AR, Holodniy $M$, Sheiner $L$, Bamberger J D, Chesney MA \& Moss A (2000). Adherence to protease inhibitors, HIV-1 viral load, and development of drug resistance in an indigent population. AIDS, 14: 357-366.

10. Gifford AL, Bormann JB, Shively MJ, Wright BC, Richman DD \& Bozzette SA (2000). Predictors of self-reported adherence and plasma HIV concentrations in patients on multidrug antiretroviral regimens. J ournal of Acquired Immune Deficiency Syndromes, 23: 386-395.

11. Zolopa AR, Shafer RW, Warford A, Montoya J G, Hsu P, Katzenstein D, Merigan TC \& Efron B (1999). HIV-1 genotypic resistance patterns predict response to saquinavir-ritonavir therapy in patients in whom previous protease inhibitor therapy had failed. Annals of Internal Medicine, 131: 813-821.

12. Wainberg MA \& Friedland G (1998). Public health implications of antiretroviral therapy and HIV drug resistance. J ournal of the American Medical Association, 279: 1977-1983.

13. Morse EV, Simon PM, Coburn M, Hyslop N, Greenspan D \& Balson PM (1991). Determinants of subject compliance within an experimental anti-HIV drug protocol. Social Science and Medicine, 32: 11611167.
14. Eldred LJ , Wu AW, Chaisson RE \& Moore RD (1998). Adherence to antiretroviral and Pneumocystis prophylaxis in HIV disease. J oumal of Acquired Immune Deficiency Syndrome, 18: 117-125.

15. Mothashari F, Riley E, Selwyn PA \& Altice $F$ (1998). Acceptance and adherence with antiretroviral therapy among HIV-infected women in correctional facility. J ournal of Acquired Immune Deficiency Syndromes and Human Retrovirology, 18: 341-348.

16. Haubrich RH, Little SJ , Currier J S, Forthal DN, Kemper CA, Beall GN, J ohnson D, Dube MP, Hwang JY \& McCutchan J A (1999). The value of patient-reported adherence to antiretroviral therapy in predicting virologic and immunologic response. AIDS, 13: 1099-1107.

17. Chesney MA, Ickovics J R, Chambers DB, Gifford AL, Neidig J , Zwickl B \& Wu AW (2000). Self-reported adherence to antiretroviral medication among participants in HIV clinical trials; the AACTG Adherence Instruments. AIDS Care, 12: 255266.

18. Kastrissios $H$, Suarez J R, Katzenstein $D$, Girard P, Sheiner LB \& Blaschke TF (1998). Characterizing patterns of drugtaking behavior with a multiple drug regimen in an AIDS clinical trial. AIDS, 12: 2295-2303.

19. Gordillo V, Del Amo J , Soriano V \& Gonzalez-LahozJ (1999). Sociodemographic and psychological variables influencing adherence to antiretroviral therapy. AIDS, 13: 1763-1769.

20. Singh $N$, Squier $C$, Sivek $C$, Wagener $M$, Nguyen MH \& Yu VL (1996). Determinants of compliance with antiretroviral therapy in patients with human immunodeficiency virus: prospective assessment with implications for enhancing compliance. AIDS Care, 8: 261-269.

21. Kleeberger CA, Phair JP, Strathdee AS, Detels R, Kingsley $L \&$ J acobson LP (2001). Determinants of heterogeneous 
adherence to HIV-antiretroviral therapies in the Multicenter AIDS Cohort Study. J ournal of Acquired Immune Deficiency Syndromes, 26: 82-92.

22. Nemes MIB, Souza MM, Souza A, Grangeiro A, Souza RS \& Lopes J F (2000). Prevalência da aderência e fatores associados. In: Ministério da Saúde do Brasil, Coordenação Nacional de DST AIDS (Editores), Aderência ao Tratamento por Anti-Retrovirais em Serviços Públicos no Estado de São Paulo. Ministério da Saúde do Brasil, Brasília, DF, Brazil, 65101.

23. Kalichman SC, Ramachandran B \& Catz S (1999). Adherence to combination antiretroviral therapies in HIV patients of low health literacy. J ournal of General Internal Medicine, 14: 267-273.

24. Catz SL, Kelly J A, Bogart LM, Benotsch EG \& MCAuliffe TL (2000). Pattems, correlates, and barriers to medication adherence among persons prescribed new treatments for HIV disease. Health Psychology, 19: 124-133.

25. Tuldrà $A$, Fumaz $C R$, Ferrer $M J$, Baynés $R$, Arnó A, Balagué $M$, Bonjoch $A$, J ou $A$, Negredo E, Paredes R, Ruiz L, Romeu, J, Sirera G, Tural C, Burger D \& Clotet B (2000). Prospective randomized two-arm controlled study to determine the efficacy of specific intervention to improve longterm adherence to highly active antiretroviral therapy. J ournal of Acquired Immune Deficiency Syndrome, 25: 221-228.
26. Samet J H, Libman $H$, Steger KA, Dhawan RK, Chen J, Shevitz AH, Dewees-Durk R, Levenson S, Kufe D \& Craven DE (1992). Compliance with zidovudine therapy in patients infected with human immunodeficiency virus type 1: a cross-sectional study in a municipal hospital clinic. American J ournal of Medicine, 92: 495-502.

27. Ickovics J R \& Meisler AW (1997). Adherence in AIDS clinical trials: A framework for clinical research and clinical care. J ournal of Clinical Epidemiology, 50: 385-391.

28. Max B \& Renslow S (2000). Management of adverse effects of antiretroviral therapy and medication adherence. Clinical Infectious Diseases, 30 (Suppl 12): S96-S116.

29. Bandura A (1995). On rectifying conceptual ecumenism. In: Maddux JE (Editor), Self-Efficacy, Adaptation, and Adjustment: Theory, Research, and Application. Plenum Press, New York, NY, USA, 347375.

30. Leite JCC, Drachler ML, Centeno MO, Pinheiro CAT \& Silveira VL (2002). Escala de auto-eficácia para adesão e tratamento para HIV/AIDS: desenvolvimento, confiabilidade e validade de construto. Psicologia Reflexão Crítica, 15: 121-133.

31. Saag MS, Holodniy M, Kuritzkes DR, O'Brien WA, Coombs R, Poscher ME, J acobsen DM, Shaw GM, Richman DD \& Volberding PA (1996). HIV viral load markers in clinical practice. Nature Medicine, 2: 625-629.

32. Murri R, Ammassari A, Gallicano K, De
Luca A, Cingolani A, J acobson D, Wu AW $\&$ Antinori A (2000). Patient-reported nonadherence is related to protease inhibitor levels. J ournal of Acquired Immune Deficiency Syndrome, 24: 123-128.

33. Bandura, A (1997). Self-Efficacy: The Exercise of Control. W.H. Freeman \& Company, New York, NY, USA.

34. Gallant J E \& Block DS (1998). Adherence to antiretroviral regimens in HIV-infected patients: results of a survey among physicians and patients. J ournal of the International Association of Physicians in AIDS Care, 4: 32-35.

35. Basen-Engquist K (1992). Psychosocial predictors of "safer-sex" behaviors in young adults. AIDS Education and Prevention, 4: 120-134.

36. Kasen S, Vaughn RD \& Walter HJ (1992). Self-efficacy for AIDS preventive behaviors among tenth grade students. Health Education Quarterly, 19: 187-202.

37. O'Leary A, Shoor S, Lorig K \& Holman R (1988). A cognitive behavior treatment for rheumatoid arthritis. Health Psychology, 7: 527-544.

38. Gilchrist LD \& Schinke SP (1983). Coping with contraception: cognitive and behavioral methods with adolescent. Cognitive Therapy and Research, 7: 379-388.

39. Di Clementi CC, Prochaska J Á \& Gilbertini $M$ (1985). Self-efficacy and self-change of smoking. Cognitive Therapy and Research, 9: 181-200. 